\title{
Sürgünden Sahneye Dönen Günah Keçisi: İo
}

\section{Exiled Scapegoat Returns to the Stage: Io}

\author{
Verda Habif ${ }^{1}$ (1)
}

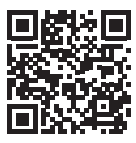

'Öğretim Görevlisi, Yeditepe Üniversitesi Güzel Sanatlar Fakültesi, Tiyatro Bölümü, İstanbul, Türkiye

ORCID:V.H. 0000-0003-3399-8105

\section{Sorumlu yazar/Corresponding author:} Verda Habif,

Yeditepe Üniversitesi Güzel Sanatlar Fakültesi, Tiyatro Bölümü, İstanbul, Türkiye

E-posta/E-mail: verdahabif@gmail.com

Başvuru/Submitted: 06.04 .2021 Revizyon Talebi/Revision Requested: 16.04.2021

Son Revizyon/Last Revision Received: 29.04.2021

Kabul/Accepted: 11.05 .2021

\section{Atıf/Citation:}

Habif, Verda. "Sürgünden Sahneye Dönen Günah Keçisi: Io" Tiyatro Eleştirmenliğive Dramaturji Bölümü Dergisi 32, (2021): 95-114. https://doi.org/10.26650/jtcd.910393

\section{Öz}

Bu çalışma Studio Oyuncuları'nın 13 Kasım 2019'da 23. İstanbul Tiyatro Festivali'nin açıış oyunu olarak ilk defa gösterimini yapan ve kaynağını Grek mitlerinden alan lo oyununun tarih, şiddet, bellek, mitoloji ve güç ilişkileri bağlamında metnine ve sahnelenmesine dair dramaturjik bir analizini sunar. Bu analizin bağlamını oluşturan olgularla ilgili düşüncelerini geniş bir perspektif içinde ortaya koyan antropolog ve düşünür René Girard'ın sunduğu trajik kavramının bileşenleri arasında bulunan günah keçisi ve kurban olguları lo mitleri ile lo oyunu arasında dramaturjik bir patika çizmek için bu çözümlemede temel alınmıştır. Bu şekilde, İo'nun metni ve sahnelemesi aracılığıyla tarihsel bilincin anlatılar ve söylemler aracılığıyla toplumlarda şiddeti meşrulaştıran bir mekanizmaya dönüşmesini eleştiriye açtığı ortaya konmaktadır.

Anahtar Kelimeler: İo, Studio Oyuncuları, René Girard, Mitoloji, Günah Keçisi

\section{ABSTRACT}

This article presents a dramaturgical analysis of Studio Oyuncuları's most recent play based on Greek mythology. lo, themed on history, violence, memory, mythology, and power relations, premiered on November 13, 2019, as the inaugural stage offering of the $23^{\text {rd }}$ Istanbul Theater Festival. The study's analysis was grounded in anthropologist and philosopher René Girard's postulation of the concepts of scapegoat and sacrifice as components of the notion of tragic. A dramaturgical path was thus constructed between the lo myths and the play. The study outcomes revealed that the text and staging of lo enable criticism of the transformation of historical consciousness into a mechanism of narratives and discourses that legitimize violence in societies.

Keywords: lo, Studio Oyuncuları, René Girard, Mythology, Scapegoat 


\section{EXTENDED ABSTRACT}

Studio Oyuncuları's most recent production Io premiered on November 13, 2019, as the inaugural stage offering of the 23rd Istanbul Theater Festival. The staging of this play and its present-day text based on Greek myths challenges the mythological narratives of the West. Io is a nymph known in classical mythological texts as the princess of Argos and daughter of the river god Inachus. The play discusses concepts emanating from the revelation of biases in representations of the tragic hero Io by reconsidering the narratives based on her character. In this context, the idea of the tragic from the contemporary point of view and the political significance of revisiting myths and reviewing their functions in structuring societies are discussed via artistic performance.

The playwright and director of Io, Şahika Tekand, disassembles the mythological discourse functioning as the foundation of the Western society through an aesthetic deconstruction of the myths that construct the narratives surrounding this character. Therefore, this study resorted to the theories mooted by the anthropologist and philosopher René Girard to dramaturgically analyze how this deconstruction works its way artistically through the play. Girard presented one of the most comprehensive perspectives on the functioning of myths in modern Western society, contemplating the relationship between tragedies, mythologies, and history; the social role discharged by myths; and the concept of the tragic. To accomplish the study objectives, a conceptual axis was drawn from Claude Levi-Strauss to Girard to better elucidate the stated ideas.

Io asks ethical questions about human existence by associating the concept of the tragic with the blindness, deafness, and amnesia of society in the face of the violence that humanity is currently subjected to in contemporary global systems. Hence, this article examines how the notion of the tragic is handled in Io by utilizing the conceptual constructs of the scapegoat and sacrifice, components of Girard's theory of tragedy, to scrutinize the myths of this ancient hero. The study's rationale establishes a dramaturgical link between the play and Girard's approach, which elucidates the use of narratives and discourses to effect the transformation of historical consciousness into a mechanism that legitimizes violence in societies. Accordingly, this paper aims to contribute to the relevant scholarship by enlightening the dramaturgical foundation of the text and staging of Studio Oyuncuları's Io, rather than attempting to offer a critical discussion of Girard's approach to the concept of the tragic.

Nevertheless, the relevance of this study to Girard's theory is not limited to a simple summary of his ideas and pivotal concepts. Instead, this paper also intends to apply these concepts to the analysis of myths concerning Io, a task that has not yet been accomplished. Thus, while aiming to contribute to the literature on the study of these myths through Girard's perspective, this paper also demonstrates that the play Io purposes to create mythical distress by deconstructing reader or viewer perceptions of mythological discourse, the formation of which is illuminated by the Girardian analysis. 
Girard analyzes the tragic cycle of the system mentioned here via the phenomena of the scapegoat and victim. This perspective illuminates how violence operates via a historical mechanism. Girard points to the persecution that occurs through narratives that reveal the views of the writers of history. In directing the viewer's gaze to this persecution, Io aims to express that violence exists both in the act of persecution and its consequent distortions, oblivion, and inaction. In the last episode of the play, Prometheus extends an invitation to humanity to claim its power and will instead of accepting the role of again becoming the persecutor in the cycle of violence.

To conclude, the text and the staging of Io criticizes myths, heroes, anti-heroes, and indeed every icon that humanity has created to enable the functioning of the contemporary world order in which we live. In so doing, Io's text and staging reveal the veiled violence that forms the essence of the Western society, proposing that real change can be achieved by a radical confrontation and an exodus from the cycle of the system. 


\section{Giriş}

İlk defa 13 Kasım 2019'da 23. İstanbul Tiyatro Festivali'nin açılış oyunu olarak sahnelenen ve Studio Oyuncuları ile İstanbul Kültür ve Sanat Vakfı'nın ortak yapımı olan İo, Grek mitlerine dayanarak günümüzde yazılmış metni ve sahnelemesi aracılığıyla Batı'nın mitolojik söylemiyle hesaplaşır. Oyun, nehir tanrısı İnakhos'un kızı Argos prensesi İo'nun trajik öyküsünü yeniden ele alışılya, mitolojik metinlerde ve aktarımlarda İo'nun temsil ediliş biçiminin ardına bakıldığında açığa çıkan kavramları tartışmaya açar. Bu bağlamda, günümüzde toplumları var eden mitleri ve trajik olanı konuşmanın politik yanı vurgulanır.

Modern Batı toplumu açısından mitlerin işlevine ve onları konu alan tragedyaların tarihle ve mitolojiyle ilişkilerine dair en bütünlüklü bakış açılarından birisini antropolog ve düşünür René Girard sunar. Bu çalışma da, mitlerin toplumsal işlevi ve trajik olan açısından Studio Oyuncuları'nın İo oyununun Girardcı kavramlardan yardım alarak dramaturjik bir analizini sunmayı amaçlamaktadır. Ío oyununun dramaturjik çıkış noktası mitoloji ile toplumsal düzen ilişkisi bağlamında trajik olanı günümüzde insanlığın sistem içinde maruz kaldığı şiddete karşı kör ve sağır eden belleksizlikle ilişkilendirerek insanın varoluşuna dair etik sorular sormaktır. Girard'ın sunduğu trajik olgusunun bileşenleri olan günah keçisi ve kurban kavramları ile mitleri kıyımcı bakış açışı üzerinden analiz ederek tarihsel bilincin anlatılar ve söylemler aracılı̆̆ıyla toplumlarda şiddeti meşrulaştıran bir mekanizmaya dönüşmesine dair ortaya koyduğu yaklaşım, Grek mitlerinin trajik kahramanlarından Argos prensesi İo'ya dair mitlerle İo oyunu arasında dramaturjik bir köprü kurarak trajik olanın hangi bağlamda ele alındığını ortaya çıkarmak için oldukça elverişlidir. Buna bağlı olarak, bu makale Girard'ın trajik olana yaklaşımına veya $\dot{I} o$ oyununa dair eleştirel bir tartışma sunmaya çalışmaktan ziyade bu ikisini yan yana getirerek söz konusu oyunun dramaturjik zeminini metni ve sahnelemesi ile ilişkilendirmek suretiyle aydınlatarak alana katkı sağlamayı amaçlamaktadır. Bu bağlamda, Girard'ın, düşüncelerine eleştirel yaklaşmasına rağmen, mitoloji, toplum ve tarih arasındaki ilişkiye dair sorduğu soruları yerinde bularak baz aldığı düşünürlerden Claude Lévi-Strauss'un yapısalcı yaklaşımına da, Girard'ın mit, tarih, dil ve kültür arasında kurduğu bağlantıların kaynakları açısından kısaca değinilecektir.

Şunu da belirtmek gerekir ki, bu çalışmadaki girişimin Girard'la alakalı kısmı İo mitlerini onun anahtar kavramları aracılığıyla bir analize tabi tutmayı içerir; böylece bir yandan bu mitlerin çözümlenmesine dair literatüre bir katkıda bulunmak amaçlanırken, diğer yandan $\dot{I o}$ oyununun bu çözümlemenin aydınlattı̆̆ tarihsel bakış açısını estetik öğeleri ve biçimsel kurgusu aracılığıyla yapıbozumuna uğratarak mitsel bir sarsılma yaratmayı amaçladığı gösterilmeye çalışılacaktır.

Io'nun yazarı ve yönetmeni Şahika Tekand'ın, 2000'li yılların başlarında yaptığı Oidipus Üçlemesi, 'günümüzde tragedyanın ve trajik olanın ne anlama geldiği' sorusunu temel alır. 
Oidipus Üçlemesi, çağdaş insanın temel tragedyasının tragedyasını yitirmiş olması düşüncesi üzerine şekillenmiştir. Biçimsel özellikleri ve metni itibariyle bu üçlemeye bilinçli olarak göz kırpan İo, aynı zamanda Aiskylos'un Zincire Vurulmuş Prometheus tragedyasına günümüzde yazılmış bir devam metni olarak da okunabilir. Bu doğrultuda İo'yu yine Tekand'ın, uluslararası bir proje olan Promethiade ${ }^{1}$ kapsamında Zincire Vurulmuş Prometheus'tan yola çıkarak yazdığı ve sahnelediği On Adımda Unutmak (Anti-Prometheus) adlı oyununun devamı olarak yorumlamak da yerinde olacaktır. On Adımda Unutmak (Anti-Prometheus), Prometheus'un verdiği ateşle yolu aydınlanan insanoğlunun sınıf atlamak uğruna kim olduğundan ve geçmişinden vazgeçmesi sonucunda günümüzde gömülmüş bulunduğu karanlıktan söz eder ve bu oyunda çağdaş insanın en temel sorununun "unutmak" olduğu vurgulanır. Bu hafıza kaybı teması Tekand'ın neredeyse diğer bütün oyunlarında da merkezdedir. ${ }^{2}$ Keza, Io' da da, Tekand temel yapıyı bu hafıza kaybı üzerine kurar; bilgi, ateş, irade, görme, düşünme ve hatırlama gibi kavramlar üzerinden toplumsal belleği zayıflayan ve yok olan toplumlara yeni bellekler inşa eden anlatıları çağımızda iktidarların statükoyu sürdürebilmek için dayandığı en büyük dayanak şeklinde ele alıp buna dair eleştirel bir tartışma ortaya koyar. Oyunun bu eleştirel bakışı nasıl sağlamaya çalıştığını inceleyebilmek için öncelikle hesaplaştığı temel meseleye bir bakmak yerinde olacaktır. Bu mesele tarih, gerçeklik, mitler ve tragedya arasındaki ilişkinin bizzat kendisidir.

\section{1. "Mitoloji nerede biter? Tarih nerede başlar?"}

Herodotos, Akdeniz'de dolaşıp hikâyeler toplamaya başladığı günden beri, mitolojinin tarihe ve tarihsel bilince temas ettiği noktalar muğlak olmakla birlikte, bu ilişkiyi çözümlemek için yapılan çalışmalar toplumları anlamak yolunda pusula işlevi görmektedir. Bu çalışmalar keskin bir doğa-kültür ayrımı veya bu ayrımın muğlaklığı bağlamında farklı bakış açılarıyla yoğrulmaktadır.

$\mathrm{Bu}$ çerçevede birçok antropolog, tarihçi ve düşünür, tarih, mitoloji ve tragedya arasındaki ilişkiyi araştırmış ve sorgulamıştır: Bu üçü arasında doğrudan bir ilişki var mıdır? Her biri diğerine müdahale ederek ve yeni buluşlarla ötekini biçimlendirerek oluşturmakta olabilir mi? Hangisi kaynağını diğerinden almıştır? Mitlerin toplumların tarihsel bilincini oluşturmaktaki işlevi nedir? Tarihsel bilincin gerçeklikle ilişkisi nedir? Bu sorulara verilen farklı cevaplar, dünyayı, insanın toplumla ilişkisini ve bu bağlamda trajik olanı ele aldığı için kaçınılmaz olarak politiktir.

Bu konular üzerine yapısalcı bakış açısıyla çalışan Claude Lévi-Strauss'un sorusu çarpıcıdır; "Bilimsel tarih yapmaya çalıştı̆̆ımızda, gerçekten bilimsel bir şey mi yapıyoruz yoksa pür

1 Promethiade projesi 2010 yılında İstanbul 2010 Avrupa Kültür Bașkenti Ajansl, Ruhr 2010 Avrupa Kültür Başkenti, Stiftung Zollverein ve Hellenic Festival ortaklığında gerçekleşmiştir. Projeye Türkiye'den Studio Oyuncuları, Yunanistan'dan Attis Tiyatrosu ve Almanya'dan Rimini Protokoll katılmıştır. Her topluluktan Aiskylos'un Zincire Vurulmuş Prometheus'undan yola çıkarak birer eser üretmeleri istenmiştir.

2 Özellikle Karanlık Korkusu (2008) başlı başına bu temanın işlendiği bir oyundur.

3 Claude Lévi-Strauss, Mit ve Anlam, çev. Gökhan Yavuz Demir, (İstanbul: İthaki Yayınları, 2013), 56. 
tarih kılmaya çalışarak kendi mitolojimizin içinde mi sıkışıp kalıyoruz?"4 Tarihle mitoloji arasındaki bu muğlak ilişkiyi sorgulayan Lévi-Strauss, öncelikle, mitler aracılığıyla kültürü kuran mekanizmayı irdelemiştir. ${ }^{5}$ Ona göre, "mit, doğasında bulunan rasyonel mantık yapısı sayesinde insanın kültürü üretebilmesini sağlamıştır. "6 Lévi-Strauss, toplumların varlıklarını sürdürebilmek için düzensizliği düzene sokma ihtiyacı duyduklarını ve bunu sağlamak için de ayırma, bölme ve sınıflandırma mekanizmalarına başvurduklarını belirtir. ${ }^{7}$ Bu mekanizmanın bir sonucu olarak ortaya çıkan mitolojiyi "insanın doğal yaşamdan kültürel evreye geçiş döneminin düşünce ve söylem yapısı olarak" tanımlar ve iddiasını Mit ve Anlam adlı eserinde "Mit bir dil biçimidir" "diyerek güçlü bir ifadeyle ortaya koyar. René Girard ise, tartışmayı Lévi-Strauss'un bıraktığı yerden daha ileriye taşıyarak dikkatimizi bu sembolik düzlemin ortaya çıkışına, yani kökenindeki gerçek toplumsal koşullara doğru yöneltir. ${ }^{10} \mathrm{O}$ da, düzensizliği düzene sokan mekanizmanın dilin ta kendisi olduğunu ve bu şekilde dilin kültürün kurucu unsuru haline geldiğini ifade eder; "Ayrım, dışlama ve birbirine bağlanma mekanizmaları kurucu sürecin ürünleridir." "11 Ancak Girard'a göre toplumları anlayabilmemiz için bu kurucu sürecin şiddet olgusuyla ilişkisine de bakmak gereklidir. Bu düzensizliğin hem temelindeki hem de yaratıcısı olan toplumsal koşulların kontrolsüz bir tür şiddete yol açtığını vurgular. Bu düzensiz durumu ehlileştirmek için ise dilin devreye girdiğini savunur: "kontrol edilemeyen olgular bir kontrol izlenimi yaratmak amacıyla sık sık yeniden adlandırılır."12 Keza, adlandırmak ehlileştirici bir tür şiddet içerir. Girard, bu edimin işlevinin kaosun yol açacağı kötücül bir tür şiddeti engellemek olduğunu vurgular. Ona göre, tarihsel metinler ve mitler, tam da bu işlevi yerine getirmektedir; şiddeti adlandırarak bir kontrol izlenimi yaratmak ve bu karmaşayı sağaltmak.

Girard, toplumsal düzlemde var olan bu şiddetin tarihsel metinler ve mitler aracılığıyla ehlileştirilme mekanizmasının işleyişinin bir takım ortak özelliklerde tespit edilebileceğini öne sürer. Öncelikle, toplumlarda şiddetin ortaya çıkmasının sebebinin farklılıkların yitimi olduğunu vurgular: "Düzen, barış ve bereket kültürel farklılıklara dayanıyor. Düşmanlığı çı̆̆ırından çıkaran farklılıklar değil, farklılıkların yitimidir. "13 Farklılıkların yitimine toplumsal veya doğaya dair (doğal afetler gibi) krizler sebep olur; bu krizler toplumları böler, dağıtır ve şiddetin çı̆̆ırından çıkmasını tetikler. Şiddet şiddeti doğurur ve bir kar topu gibi büyüyerek

$4 \quad$ A.g.e., 59.

5 Lévi-Strauss'un, Girard'ın ve başka diğer antropolog, düşünür ve kültür tarihçilerinin bu konudaki düşüncelerine dair ayrıntılı ve karşılaş̧ırmalı bir tartışma için bkz. Oğuz Arıc1, "Muğlâklık ve Tragedya" (Doktora tezi, İstanbul Üniversitesi, 2009), 82-86.

6 Ahmet Uğurlu, “Claude Lévi-Strauss’ta Mitos”, İnsan \& Toplum Dergisi 4/7 (2014), 122.

7 Lévi-Strauss, Mit ve Anlam, 25-33.

8 Uğurlu, "Claude Lévi-Strauss'ta Mitos", 113.

9 Lévi-Strauss, Mit ve Anlam, 8.

10 Girard'ın Lévi-Strauss üzerine düşünceleri için bkz. René Girard, Siddet ve Kutsal, çev. Necmiye Alpay (İstanbul: Kanat Yayınları, 2003), 317-360.

11 A.g.e., 337.

12 René Girard, Günah Keçisi, çev. Işık Ergüden, (İstanbul: Alfa Yayınları, 2018), 12.

13 Girard, Siddet ve Kutsal, 68. 
toplumun düzenini alt üst eder. Bu kontrolsüz şiddetin yol açtığı kaosu düzene sokmanın yolu iyicil olarak görülen bir tür şiddetin dikkatli ve kontrollü uygulanışıdır. Bu da şu şekilde cereyan eder: Eğer toplumun içinden bir kişinin ötekilerden daha suçlu olduğuna inanılırsa bu suç fikri insanların kolektif etkileşimini yaratacaktır. Bu şekilde, öldürülmesi ya da toplumdan dışlanması, sürülmesi gereken bir kurban fikri oluşur ve herkes ona karşı birleşir. Herkesin ortak olarak suçladığı bu kişi, şiddetin çığırından çıkmasının sorumlusu olarak ilan edilir ve toplumun “günah keçisi ”ne dönüşür. Günah keçileri ancak öldüklerinde veya sürüldüklerinde toplumdan şiddetin yarattığg kirliliği temizleyerek, barış getirirler. Böylece, en büyük kabahatli, toplumun başlıca dayanağı haline gelir. Kutsallık ya da kurban fikrinin kaynağında da bu süreç işler. Öyle ki, kutsal olan hem soyludur hem de lanetli. Ancak Girard'a göre bütün bu süreç, kıyımcıların bakış açısından üretilmiş bir yanılsama üzerine kuruludur, çünkü, günah keçisi mekanizması aslında krizin kaynağı olan sorunu çözmez, bu sorun nedeniyle ortaya çıkan insan ilişkilerindeki bozulma üzerinde etkili olur ve bu sırada sorunun nesnel kaynağ 1 üzerinde etkili olduğu izlenimini yaratır. Böylece kaotik gerçeklik sembolik düzlemde düzene sokulmuş olur, tıpkı dilin yaptığı gibi.

Girard'a göre, mitlerin işlevi düzeni sağlamak için toplumun temelindeki kurucu şiddeti ayinleştirerek anımsatmaktır. Keza mitlere bakınca hepsinde aynı örüntünün bulunduğu görülür: bir kişinin bütün bir toplum tarafından öldürülmesi veya sürgüne gönderilmesi. Devletler de bu günah keçisinin ayinsel cinayeti üzerine yapılarını inşa ederler. Dolayısıyla, toplumlar şiddetin ortadan kalkması için değil, şiddetin ta kendisi üzerine kurulurlar. Tarihin, politikanın ve toplumun masumiyetine dair bütün tarihsel bilincimiz ve bakış açımız da aslında şiddetin ta kendisi üzerine varlığını inşa edenler tarafından şekillendirilir. Girard, mitleri ve tarihsel metinleri bu bağlamda, şiddetin kendisi üzerine varlığını inşa edenlerin taşıdıkları kıyımcı bakış açısını deşifre etmek üzere inceler. Ona göre bu metinler ve aktarımlar; "çoğu zaman kolektif olarak yaşanan gerçek şiddetin, klyımcıların bakış açısıyla kaleme alınmış, dolayısıla karakteristik çarpıtmalardan etkilenmiş raporlarıdır."14 Girard'a göre, kıyımcılar katliamlarının hiçbir yönünü örtbas etmeye çalışmazlar çünkü onlara göre kıyımları haklıdır. Haliyle, anlatılarda kıyımın dayandırıldığ 1 sebepler gerçek olmayabilir ama kıyımın kendisi mutlaka gerçektir. Girard, kıyımcı zihniyetin yarattığı yanılsamanın kıyımın varlığını yalanlamak yerine, doğruladığını öne sürer. Ona göre, kıyım metinlerinde ortak olarak rastlanan bir takım basmakalıpların varlığı bunu kanıtlamaktadır. Böyle metinlerde bu basmakalıplar üzerinden hem gerçek şiddetin hem de bu şiddeti meşrulaştırıcı kıyımcı zihniyetin varlığının izni sürmek mümkündür.

Girard'ın ileri sürdüğü basmakalıplardan birincisi kıyımın gerçekleşmesine neden olan şiddeti doğuran bir takım toplumsal krizlerin varlığıdır. Kıyım genellikle kriz zamanlarında meydana gelir. Bu krizler normal kurumların sarsılmasına yol açar ve sürü ya da yığın oluşumuna sebep

14 Girard, Günah Keçisi, 19. 
olur. Bu durum halihazırda gücünü ve etkisini kaybetmiş olan kurumlar üzerinde büyük ölçüde baskıya neden olabilir, hatta onları tümüyle yerlerinden edebilir. Bu krizlere bazen dişsal, bazen de içsel sebepler yol açar; kimi zaman ardından açlığın da geldiği salgınlar, aşırı kuraklık, su baskını veya politik karışıklıklar ve dinsel çatışmalar... Ancak her durumda, kültürel ayrımları tanımlayan kural ve farklılıkların silinmesine yol açarlar. Kurumların yıkılmasıyla, hiyerarşik ve işlevsel farklılıklar ortadan kalkar. Bu durumda insanların kendilerini buldukları bu yeni tanımsız durumun içinde başlarına gelen şeyi adlandırma ihtiyaçları doğar. Girard bu durumu şu şekilde açıklar; "Kültür silikleştiğinde insanlar kendilerini güçsüz hissederler; felaketin büyüklügü karşısında şaşkına dönerler ama doğal nedenlerle ilgilenmek akıllarına gelmez; bu nedenleri daha iyi tanımakla onlar üzerinde etkide bulunabilecekleri fikri rüsseym halde kalır." ${ }^{15}$ Burada aslında dağılan şey insan ilişkileridir. Fakat insanlar bununla yüzleşemezler ve sorumluluğunu alamazlar, dolayısıyla bunun yerine onlara hiçbir bedeli olmayacak şekilde müşterek bir biçimde toplumu külliyen suçlamaya ya da zararlı olduğu konusunda kolayca ortak olarak uzlaşılabilecek bir takım nedenler yaratarak başka kişilere suçu yüklemeye meyillidirler. ${ }^{16}$

İkinci basmakalıp, kolektif kıyımlardaki suçlama konuları ve kurban olarak seçilenlerin evrensel özellikleri üzerinden gerçekleşir. Girard, kınanan kişilerin yani günah keçisi olarak seçilen kurbanların kıyıma uğratılabilir kategorilere ait kişiler olmalarına dikkat çeker. $\mathrm{Bu}$ kategorilerin ölçütleri kültürel, dinsel veya fiziksel özelliklere dayanır. Azınlık olma, hastalık, delilik, genetik bozukluklar, sakatlıklar ve fiziksel anormallik ${ }^{17}$ gibi ortalamayı belirleyen toplumsal statüden herhangi bir yöne doğru uzaklaşılmasına yol açan her türlü aşırı özellik olabilir.

Üçüncü basmakalıp ise suçun niteliğindeki farksızlaştırıcı özelliktir. Girard'a göre, krizin farksızlaştırıcılığının sorumluluğunu kurbanlara atmak için, toplum onları farkların silinmesine neden olan suçları işlemekle suçlar. ${ }^{18}$ Zira, seçilen kurbanlar da genellikle bu suçlara yatkın görünür. Onlara atfedilen farksızlaştırıcı nitelikte suçlar, ele alınan kültüre göre değişir ve genelde o kültürün en mutlak tabularını ihlal eden suçlardır. Bu suçların bir diğer özelliği bireysel ile kolektif arasındaki ayrımı ortadan kaldırmaları ve çatışma hâlindeki kişilerin kimlik yitimine sebep olmalarıdır. Farksızlaştırıcı suçların bulaşıcılık yoluyla tüm topluma sirayet etme riski vardır bu nedenle tehlikeli görülürler. Baba katli, ensest, topluluğun fiziksel ya da ahlaki zehirlenmesi gibi suçlar örnek olarak gösterilebilir.

Grek mitolojisinde nehir tanrısı İnakhos'un kızı, Argos prensesi İo'nun başından geçenlere dair çeşitli söylenceler de aktarımlarında kıyımcı bakış açısının olduğunu doğrulayan bu basmakalıpları taşır. İo oyunu ise işte bu mekanizmayı tartışarak bu basmakalıpların kurmaca

15 A.g.e., 25.

16 A.g.e., 25.

17 Girard, "anormal" sözcügünün hem soylu hem lanetli olduğundan söz eder. A.g.e., 30.

18 A.g.e., 34 
niteliğini açığa çıkarır. Bunun oyunda nasıl işlediğine bakmadan önce İo mitlerine ${ }^{19}$ Girardcı bir bakış atalım.

\section{Mitolojik ve Tarihsel Kaynaklarda İnakhos'un Kızı İo ve Kurbanlık İşaretleri}

İo miti klasik antikiteden günümüze kadar oldukça popüler olmuştur. Zeus tarafindan hamile bırakılan, Hera tarafından ineğe dönüştürülen, ilkin yüz gözlü $\operatorname{Argos}^{20}$ tarafından takip edildiğinden, daha sonra da başına musallat edilmiş olan keneden ${ }^{21}$ kaçtığ için âdeta delirmişçesine başıboş bir şekilde hiç durmadan amaçsızca oradan oraya dolaşan ve yolculuğu sırasında Avrupa'dan Asya'ya kıta aşarak Argos'tan Mısır'a varan, nihayet Nil kenarında bir oğul doğuran ve tekrar insan biçimine kavuşan bu meczuba dair hikâyeler farklı versiyonlar halinde birçok kaynakta yer alır. Hatta, Herodot Tarihi İo'nun başından geçenlerin öyküsüyle başlar. ${ }^{22}$ Diğer yandan, Konstantinou'nun belirttiği üzere 5. Yüzyıl külliyatından içinde İo’nun geçtiği hiçbir metnin tarihi bile kesin olarak bilinmez; sanki İo'nun kendisi gibi bu metinlere dair bilgiler de pusulasızdır. Bu belirsizliğin içinde İo’ya üç farklı tragedyada rastlıyoruz. İlk, Aiskhylos'un Yalvaran Kadınlar'ında bir koro bölümünde İo'dan ve sürgündeki hikâyesinden söz edildiği görülür. Zincire Vurulmuş Prometheus'ta ise bu defa bir karakter olarak karşımıza çıkar. Son olarak da metni günümüze ulaşmamış olan Sophokles'in İnakhos'unda yer aldığı bilinir. Ancak bu oyuna dair kısıtlı bilgilerin ışığı İo’nun bu metinde bir karakter olarak yer alıp almadığı konusunu aydınlatmaya yetmemektedir, Yalvaran Kadınlar'daki gibi bu metinde de ondan sadece söz edilmiş de olabilir. ${ }^{23}$

Mitolojik kaynaklarda İo, bir "Naiad-nimfası"24 olarak geçmektedir. Güney Yunanistan'da bulunan Argos şehrinin kralı nehir tanrısı İnakhos'un kızıdır ve oradaki Hera tapınağında rahibelik yapar. İo'nun kaderi Zeus'un günün birinde onu görüp güzelliğine vurulmasıyla ve onunla birlikte olmasıyla değişir. Durumu öğrenen Hera'nın kıskançlığından İo’yu korumak için Zeus onu bir ineğe dönüştürür. Bunun üzerine Hera ineğin kendisine verilmesini ister, ve yüz gözlü dev Argos'u başına bekçi olarak diker. Zeus sevgilisini kurtarması için oğlu Hermes'i görevlendirir ve Hermes de Argos'u öldürür. ${ }^{25}$ Ama Hera İo'nun peşini yine birakmaz, ona bir

19 Mitolojik hikâyeler farklı tarihlere ve bölgelere ait kaynaklarda aktarılarak günümüze geldiği için birçok değişik versiyonları bulunmaktadır. Burada değerlendirme için başvuracağımız versiyon Tekand'ın oyunu için baz aldığı versiyon olacaktır.

20 Argos, bazı kaynaklarda “yüz gözlü” olarak, bazı kaynaklarda ise "bin gözlü” olarak tanımlanmaktadır.

21 Bazı kaynaklara göre bu bir at sineğidir.

22 Herodotos, Herodot Tarihi, çev. Müntekim Ökmen (İstanbul: Türkiye İş Bankası Kültür Yayınları, 2002), 31-33.

23 Ariadne Konstantinou, "Reconsidering the Metamorphosis of Io: on Texts, Images and Dates," Symbolae Osloenses 89/1 (2015), 39.

24 Nimfalar dünyada yaşayan doğa tanrıçalarıdır. Naiad nimfları su kaynakları, nehirler, göller, bataklıklar, çeşmeler ve akarsuların nimflarıdır. Bkz. Azra Erhat, Mitoloji sözlüğü (İstanbul: Remzi Kitabevi, 2011).

25 Hermes'in Argos'u nasıl öldürdüğüne dair farklı kaynaklarda farklı anlatılar bulunmaktadır. Bir söylenceye göre, uzaktan attığı bir taş ile onu öldürmüş başka bir söylenceye göre ise flütünden çıkan büyülü ezgilerle önce onu uyutup daha sonra öldürmüştür. A.g.e., 279. 
kene musallat eder. Bir türlü ona musallat olan kenenin yarattığg huzursuzluktan kurtulamayan İo, inek biçiminde, geçtiği yerlere adını vererek hiç durmadan kıtadan kıtaya atlayarak koşar. ${ }^{26}$ Bu bitmeyen yolculuğu sırasında Kafkas dağlarında bir kayaya zincirlenmiş olan Prometheus'a rastlar. Bu karşılaşma Aiskhylos'un Zincire Vurulmuş Prometheus tragedyasında geçer. Bu kısa buluşma sırasında Prometheus kehanetlerde bulunarak İo’ya kaderin kendisi için neler hazırladığını bildirir: Mısır'a varacak, orada tekrar insan biçimine girecek ve Zeus'un oğlu Epaphos'u doğuracaktır ve Akdeniz'in güney ve doğu kıyılarına iki koldan yayılacak ve daha sonra Yunanistan'a geri dönecek olan bir kral soyunun atası olacaktır. ${ }^{27}$ Efsanenin versiyonlarından birisine göre, Zeus bir gün tekrar Hermes'i gönderip İo’ya musallat olan keneden onu kurtarır ve ona ölümlülüğü bahşeder. ${ }^{28}$

Girardcı analize göre anlatılarda kıyımın varlığını doğrulayan basmakalıplardan birincisi toplumsal kriz ve farklılıkların yitimidir. İo mitinde bu basmakalıbın yer aldığını görebilmek için İo’nun Zeus tarafından hamile bırakılmasının öncesine bakmamız gerekir. İo’nun babası İnakhos, güney Yunanistan'da yer alan Argos'un nehir tanrısıdır. Efsaneye göre, Poseidon ve Hera, Argos'un hâkimiyetinin kimde olacağı ile ilgili bir ihtilafa girerler ve İnakhos'un yargıçlık yapmasını isterler. Bunun üzerine Hera’yı seçen İnakhos, Poseidon'un intikamına maruz kalır ve ceza olarak Poseidon onun (nehrinin) yatağını kurutur. ${ }^{29}$ Herodot Tarihi'nde ise İo'nun hikâyesi Fenikeliler'in mallarını satmak üzere Argos'a gelişiyle başlar. Herodot, hikâyenin Persler ve Fenikeliler tarafından farklı aktarıldığını belirtir. Perslere göre, Argos Kralı'nın kızı İo, oraya mallarını satmak üzere gemiyle gelen Fenikeliler tarafından kaçırılarak Mısır'a götürülür. Fenikelilere göre ise İo Mısır'a götürülmüştür, ancak zorla değil; Argos'ta gemi sahibiyle ilişkisi olmuş, hamile olduğunu anlayınca da kusurunu örtmek için Fenikelilerin peşinden denize kendi isteğiyle açılmıştır. Ancak her iki durumda da bu olay, tarihsel olarak Yunanlılar, Persler ve Fenikelilerin dâhil olduğu Medeia'nın ve Helen'in kaçırılmalarına kadar uzanan olayların ve Avrupa ile Asya arasındaki politik çatışmaların ve savaşların hikâyesinin başlangıcıdır. ${ }^{30}$ Sonuç olarak, anlatılarda İnakhos'un Hera'yı seçmesi nedeniyle yatağının kuruması da, İo'nun kaçırılarak ya da kendi isteğiyle Argos'tan Mısır'a gitmesi de, onu bir toplumsal kriz durumunun merkezine koyar. Girard, mitlerin işaret ettiği toplumsal krizlerin sebeplerine örnek olarak diğer birçok olayın yanında kuraklık veya politik karışıklıklardan söz eder. İnakhos'un yatağının kuruması kuraklığa işaret eder. Herodot'un aktarımındaki tarihsel olaylar ise politik karışıklıklara. Ayrıca bu krizlerin her durumda aynı olan bir özelliği vardır:

26 İstanbul'da bulunan boğazın adı Bosphoros, 'inek geçidi' anlamına gelir.

27 İo'nun başından geçenler ve farklı kaynaklarda nasıl ele alındığı ile ilgili detaylı bilgi için bkz. William Smith, Dictionary of Greek and Roman Biography and Mythology, vol. 2 (Boston: Little, Brown and Co., 1870), 575-577.

28 Tekand'ın İo'sunun da üzerinde artık fiziksel olarak onu rahatsız eden bir canlı yoktur, ancak yıllar boyunca taşıdığı huzursuzluk artık aklına ve ruhuna kazınmıştır ve artık onun bir parçası haline gelmiştir.

29 Smith, Dictionary of Greek and Roman Biography and Mythology, 571-572.

30 Herodotos, Herodot Tarihi, 31-33. 
kültürel ayrımları tanımlayan kural ve farklılıkların silinmesi. İnakhos'un Hera ve Poseidon arasındaki ihtilafı çözmek üzere yargıç konumuna atanması, ona hiyerarşik olarak kendisinden kat be kat yüksek mertebede bulunan iki tanrının üstünde bir güç bahşedilmesiyle bir farklılık yitimine sebep olur. Yine, Avrupalı İo'nun Asyalılar tarafından ele geçirilmesi ve hamile bırakılması da kültürel ayrımları tanımlayan kural ve farklılıkların silinmesine yol açar.

Girard'ın sözünü ettiği ikinci basmakalıp kurbanlık işaretleri ile ilgilidir. İo'nun Argos’ta yaşanan toplumsal krize bir cevap olarak toplumun günah keçisi seçilmesi her anlamda Girard'ın kurbanlık seçim ölçütlerine uygun olarak gerçekleşir; İo, Girard'ın tarif ettiği şekliyle kurbanlık işaretlerinin tümünü taşımaktadır. Girard, bu ölçütleri şöyle tanımlar; "Hepsi de kültürel düzenin temellerine, ailevi ve hiyerarşik farklılıklara, toplumsal düzenin olmazsa olmaz farklılıklarına saldırıdır. [...] Toplumsal bağı gevşetmekle kalmayıp tamamen yok ederler."31 Girard'a göre zengin ve güçlü olmak da kurban olarak seçilmek için yoksulluk ve zayıflık kadar geçerli bir sebeptir, çünkü bir tür aşırılık barındırmaktadır. İo da, bir kralın kızıdır ve aynı zamanda tanrıların soyundan gelmektedir. Ayrıca, İo'nun hikâyesinin ilerleyen kısımlarında yani günah keçisi seçildikten sonra ona atfedilen özellikler de âdeta kurban olarak seçilmesini meşrulaştırmaktadır. İneğe dönüştürülmesi, insan ile hayvan arasındaki farkın yitimine sebep olduğu gibi, onu tanımsız ve anormal bir varlık olarak gösterir. Ayrıca İo ona musallat olan keneden kaçarak aklını yitirmişçesine kıtalar arasında dolanmaktadır. Akli dengesizlik de Girard'ın kurbanlık işareti olarak tanımladığı ölçütlerden birisidir.

Son olarak suçun farksızlaştırıcılığı basmakalıbını da İo mitinde görürüz. İo ile ilgili anlatımlar onun Zeus tarafından baştan çıkarıldığını vurgular. ${ }^{32}$ Buna göre, İo'nun suçu baştan çıkmasıdır. Üstelik kendisi Hera tapınağına adanmış bir rahibedir. Dolayısıyla kendisini Hera'ya adamış bir tapınak rahibesinin baştan çıkmasının toplumun en mutlak tabularını ihlal eden bir suç olduğu kuşku götürmezdir. Kabahati ve sonrasında şehrinden sürülmesi İo’yu kutsal mertebesinden ve kralın kızı olarak ayrıcalıklı konumundan mahrum eder ve onu sıradanlaştırır.

Sonuç olarak İo, günah keçisi ilan edilerek Argos’tan sürülür ve artık lanetlidir. Girardcı bir okuma İo mitinin kıyımcı niteliğini gözler önüne serer. Tekand da, İo oyununda tam da mitin üzerindeki bu örtüyü kaldırmakla ilgilenir. Oyunda, mitolojik olarak İo'nun bir günah keçisi olarak seçilmesiyle sağlanan toplumsal düzen anlatısının kendisini sorgular. Günah keçisi mekanizmasının meşrulaştırıcı yanılsamalarını birer birer sorgulayarak bu mekanizmayı âdeta

31 Girard, Günah Keçisi, 26.

32 İo'nun Zeus tarafından baştan çıkarılmış ya da tecavüze uğramış olarak tanımlanması daha derinlemesine tartışılabilir. Herodotos da, bu bağlamda Fenikeliler ve Persler tarafından aktarılan farklı iki yaklaşıma değinmiştir. Perslere göre İo daha pasiftir, Fenikeliler'e göre ise kendi iradesiyle hareket etmektedir. Bu konuda daha fazla ayrıntılı bir tartışma için bkz. Emily K. Anhalt, "The Tragic Io: Defining Identity in a Democratic Age," New England Classical Journal 42/4 (2015), 246-260. Buradaki analiz açısından bu tartışmaya yer verilmesi gerekli görülmemiştir çünkü her halükarda, İo suçlu ve kurban durumuna düşer. Mesele, zaten tam da suçun ona yüklenmesidir. Dolayısıyla burada suçun ona yüklenmesinin yarattığı yanılsamanın altını çizmek için baştan çıkartıldı̆̆ı yönündeki söylem temel alınmıştır. 
bir mahkeme salonuna taşıyan yine İo'nun kendisi olacaktır. Oyun bir nevi, günah keçisi geri dönerse ne olur sorusu üzerinden ilerler. Oyunda toplumsal düzenin temelinde yatan şiddet sorgulanırken, adaletsizlik ve yanılsama üzerine kurulu bu düzen anlayışının derinine inilerek adalet kavramı masaya yatırılır. Ancak Tekand'ın oyununda İo'nun geri dönüşünün sebep olduğu mitsel sarsılma hakkında daha detaylı bir analiz yapmadan önce oyunun öyküsüne ve yapısına bir bakalım.

\section{Studio Oyuncuları'nın İo'su}

Tarih boyunca Prometheus mitini merkeze alan birçok eser vardır. Tekand da eserinde Prometheus mitini ele alır ancak bunu yaparken mitolojinin şiddeti meşrulaştıran ve sağaltan kıyımcı bakış açısını birden fazla katmanda sarsmayı amaçlar. Bunu da oyunun konusu olan mitolojik anlatıların dayanaklarını alt üst ederek yapar. Öncelikle hikâyenin merkezine Zincire Vurulmuş Prometheus'ta ve kendisinden söz edilen diğer Antik oyunlarda sadece bir yan karakter olan İo'yu yerleştirir ve onu sürülmüş olduğu Argos şehrine geri getirerek şehirden sürülmesini meşrulaştıran mekanizmayı sorgulatır. Daha sonra ise Prometheus karakteri aracılığıyla oyunun içindeki tartışmayı bir kısır döngü içine hapseden sistemi de sorgulatacak yeni bir bakış açısı getirerek kendi kurduğu düzene seyirciyle birlikte kuşbakışı bakar. Yani, Tekand eleştirel yaklaşımını sadece mitolojinin sürülmüş, kenara atılmış bir karakterin gözünden aktarılması ile sınırlandırmaz, daha da ileri giderek oyunun içinde bu bakış açısını da ters yüz edip, son epizotta İo ile Prometheus arasındaki diyalogla mitleştirmenin kendisini eleştiriye açar.

Oyun, daireler çizerek sonsuz bir yolculuk içinde dünyayı dolaşmaktan yorgun düşmüş, hem kendi uğradığı adaletsizlik hem de yolculuğu sırasında tanık oldukları nedeniyle ruhu bir türlü huzura kavuşamayan ve artık tek arzusu doğduğu topraklarda ölmek olan İo'nun Argos'a, yani kendi memleketine gelişiyle başlar. Çok geçmeden karşısına topraklarına gelen bu yabancının kim olduğunu anlamak isteyen Argos halkı çıkar. Halk, dışarıdan gelen, farklı davranan, acı içinde kıvranan, sorular sorarak sessizliği ve huzuru bozan bu yabancının kim olduğunu öğrenmek ister. Onun geçmişte bu topraklardan sürülmüş ve lanetli olarak bilinen İo olduğunu duyduğunda ise dehşete kapılarak onu oradan göndermek ister. Ancak bu karşılaşma sırasında geldiği yerin yıllardır aradığı doğduğu topraklar olduğunu anlayan İo, orada kalmak için yalvarır. Argoslular ise İo’yu geçmişte Zeus'u baştan çıkartıp onunla birleşmesi ve bu günahı yüzünden de topraklarından sürülmesiyle bilmektedirler; onun bu topraklara geri gelişinin lanet ve felaket getireceğinden korkarlar. İo, hakkını savunmak için kendisi hakkındaki gerçeklerin aslında onlar tarafından bilindiği gibi olmadığını, onunla ilgili efsanelerin bir başka yüzünün olduğunu anlatır. Zeus'un onunla rızası olmadığı halde birleştiğini ve babasının da onu Hera'dan korkan Zeus'un zoruyla ve tehditleriyle topraklarından gönderdiğini söyler. İo'nun anlattıklarıyla şimdiye kadar bilinenlerin çatışması halkın korku, inkâr, acıma ve kuşku arasında kalmasına ve huzursuzlanmasına yol açar. İo, bunun üzerine onları ikna etmek amacıyla başından geçenleri ve sürgünde yaşadıklarını daha detaylı bir şekilde açıklamaya başlar. Sürgündeyken karşılaştı̆̆g ve 
Zeus'un iktidarının mutlak olmadığını ona söyleyerek umut veren Prometheus'tan bahsettiğinde ise onun insanlık tarafından çoktan unutulmuş olduğunu anlar. İnsanları ikna etmek için son umudu da boşa çıkan İo, haklılığını kanıtlamaya karar verir ve kesinlikle gitmeyeceğini açıklar. Bunun üzerine onu göndermek üzere Zeus'un kirli işlerini gören iblis kardeşler Kratos ve Bia gelirler. Aşağılayarak ve tehditlerle İo’yu göndermeye çalışırlar. İo ise onlara meydan okur. Aralarındaki çatışma sırasında bilinen gerçekler yeniden tartışmaya açılır ve bu durum halkta kafa karışıklığına, sorgulama ve muhakeme sürecinin başlamasına sebep olur. İo'nun her şeyi göze almak pahasına susmayacağını anlayan Kratos, onu başkalarının da başına felaket getirmekle suçlayarak korkutmaya çalışır ancak İo, bunun da sorumluluğunu almaya hazırdır. Hatta daha da ileri giderek doğrudan Zeus'a meydan okur ve Zeus'un, iktidarının bir gün son bulacağını bildiren kehanetten ${ }^{33}$ korktuğunu söyler. Zeus'un da bir sonunun olduğu bilgisinin ifşa edilmesi Kratos'un İo’yla tartışırken dayandığı gücün mutlaklığını sarsar. Kratos çaresizce onu susturmaya çalışır fakat İo artık susmama konusunda kararlı olduğunu belirtir. İo ve Kratos arasında geçen tartışma ve İo'nun Kratos karşısındaki ölçüsüz cesareti halkta önce korkunun yükselmesini daha sonra kuşku, kafa karışıklığı ve muhakemeyi tetikler. Zihinler hatırlanacak bir şey olduğunu hatırlatmaya başlar... Cezalandırılmaktan, ortalığın karışmasından, felaketlerin ortasında kalmaktan korkan ama sorgulamaktan kendini alamayan insanlar dehşete kapılırlar. Kratos ve Bia'nın tehditleri İo'yu göndermeye yetmeyince ve halk iyice huzursuzlanmaya başlayınca Zeus'un oğlu Hermes gelir. Türlü stratejilerle İo'nun gitmesini sağlamaya çalışan Hermes de onu susturamayacağını anlayınca eğer günahlarını kabul eder ve Zeus'a bağlılık yemini ederse Zeus'un onu affedeceğini ve acılarına son vereceğini söyler. İo, ancak eğer adalet yerini bulursa susacağını söyleyerek açıkça adalet talep eder ve hatta Zeus'un ona yaptığı haksızlığın hesabını vermesi gerektiğini öne sürer. Zeus'un onu çoktan öldürmemiş olmasının sebebinin kendisinden almak istediği bir bilgiyle alakalı olduğunu söyleyerek kozunu kullanır ve zamanı geldiğinde Zeus'un iktidarının son bulacağını hatırlatır. İo’yu ikna edemeyen Hermes, İo'nun gücünü aldığı umudun temsilcisi Prometheus'a saldırır ve Prometheus'un artık onun için umut olamayacağını ima eder. Eryniler' in $^{34}$ de artık intikam perileri olmaktan çıkıp Olympos'un eteklerinde yaşadıklarını söyleyerek İo’yu yalnızlaştırarak sindirmeye çalışır. Bütün bunlar konuşulurken halkta kafa karışıklığı, kuşku ve sorgulama durdurulamaz bir şekilde artar. Artık olayların tartışılması ve sorgulanması kaçınılmaz olmuştur; hatırlama başlar ve topluluk içinde kopmalara ve kırılmalara sebep olurken öfke, acı ve isyan topluluğa sirayet etmeye ve yükselmeye başlar. Aynı zamanda öfke duymaktan duyulan korku insanların ne yapacaklarını bilmeden çırpınmalarına sebep olur. İo’nun inadı ve topluluğun giderek çığırından çıkması

33 Bu kehanet Zincire Vurulmuş Prometheus'da geçer. Bkz. Aiskhylos, Zincire Vurulmuş Prometheus, çev. Azra Erhat ve Sabahattin Eyüboğlu (İstanbul: İş Bankası Yayınları, 2000). Zeus'un akıbetinin kimin elinden ve nasıl olacağını Prometheus bilmektedir. Zeus Prometheus'un bu bilgiyi İo ile paylaştığını düşünmektedir.

34 Aiskhylos Eumenidler oyununun sonunda intikam perileri Eryniler Athena tarafından ikna edilerek intikam perisi olmaktan çıkarılırlar. Bkz. Aiskhülos, Oresteia: Agamemnon, Adak Sunucular, Eumenidler, çev. Y1lmaz Onay (İstanbul: Mitos Boyut Yayınları, 2016). 
karşısında Hermes son kozunu oynamaya karar verir ve İo'nun bütün umudunu bağladığı Prometheus'u zincirlerinden kurtulmuş ve Olympos'un esiri olmuş haliyle karşısına getirir. Prometheus şaşkınlık içindeki İo'ya Zeus'a kaçınılmaz akıbetinden nasıl kurtulacağı bilgisini vermediği için Tartaros'a gönderilmediğini ancak daha ağır bir cezaya çarptırıldığını açıklar. Zeus onu dünyada olup biten her şeyi görüp işitebildiği ama insanoğluna hiç bir biçimde erişemeyeceği bir yerde sonsuza kadar yalnızlığa mahkûm etmiştir. İo ısrarla ona gücünü hatırlattığında ise Prometheus gücü onda ya da Zeus'ta aramasının doğru olmadığını söyler. Prometheus insanlığı ancak kendi iradesinin kurtarabileceğini anladığını söyler. Prometheus'u oraya başka bir amaçla getirmiş olan Hermes ise onu susturmak ister. Hermes'in saldırılarına cevap verirken Prometheus Zeus'un akıbetiyle ilgili kehaneti İo’ya söylememiş olduğunu ele vermiştir. Böylece İo, kehanetin bilgisine sahip olmadığı için artık gözden çıkarılabilir konuma getirilmiş olur. Hermes artık durumu kontrol altına alamayacağını anladığında Prometheus'u İo'nun hayatına son vererek cezalandırır ve esaretine geri gönderir. Geçmişi hatırlayan ve kendi iradesizlikleri ile yüzleşen insanlar ise acı ve öfkeden neredeyse katatonik hale gelmişlerdir. Tanrılar ortadan kaybolup yalnız kaldıklarında bir süre tepkisizlikten sonra, artık hareketsiz kalamadıklarını görürüz.

Oyunun edebi öyküsü bu şekilde gerçekleşir. Sahnelenme biçiminin hangi ilkelere dayanarak kurulduğunu da irdeleyelim.

Işık, gölge, ses, sessizlik, hareket ve hareketsizlik üzerine kurulu olan oyunda metnin yapısı ve sahne düzeni, karakterler arasında geçen, gerilimi gittikçe artan tartışma ve bu tartışmaya Koro'nun verdiği tepkiler üzerinden şekillenmiştir. Sahnedeki performansın yöneticisi 1şıtıtı. Oyun boyunca tüm rol kişilerinin ve Koro'nun 1şıkla ilişkisi iki katlı bir yapı içine yerleşmiş oyuncuların her birini ayrı ayrı aydınlatan veya karanlıkta bırakan bir düzen taşır ve bu düzenin içinde gerçekleşen farklı durumların metinle örtüşmesi anlam üretir, metnin anlamını boyutlandırır. Bu farklı durumlar, tam ışık altında konuşma veya susma, gölgeden ışığa girerek konuşma veya susma, 1şıktan çıkarak konuşma veya susma şeklinde gerçekleşir. Tekand'ın reji notları şöyle der; "Işık/karanlık çelişkisi, ışıkta ses-suskunluk çelişkisi, ışıkta harekethareketsizlik çelişkisi oyunun anlamını taşıyan asal unsurlardır." ${ }^{35}$

Işık, oyuncuların görünürlüğünü sağlayan unsur olarak insanın içinde yaşadığı dünyadaki varoluş koşulunu ifade eder. Yaratılış mitinden itibaren Zeus'un temsil ettiği dünya kavrayışına bağlı olarak tanımlanan tarihsel bilinç gibidir. Bu noktada Girard'ın tarihin, politikanın ve toplumun masumiyetine dair bilincimizin ve bakış açımızın aslında şiddetin ta kendisi üzerine varlığını inşa edenler tarafından şekillendirildiğini öne sürdüğünü hatırlayalım. Girard, bu tespitini sadece kurban ekonomisine dayalı ilkel toplumlarda değil, modern yargı sisteminin kuruluşunda da aynı şiddet sarmalının olduğu teorisi üzerine temellendirir: "Nöbeti kurban

35 Şahika Tekand, "İo Reji Notları" (İstanbul:2019). 
ediminden devralan yargı sistemi de aynı karanlıkla sarmalanır. Suçlu ve yasa dışı bir şiddetin içkinligi karşısında, kutsal, yasal ve meşru şiddetin etkili aşkınlıgıyla örtüşür bu karanlık." "36 Zeus ve onu yaratan, varlığını meşru kılan mitolojik külliyat bu aşkın karanlıkla örtüşür. Bu karanlık kendisini şiddetli aydınlatıcılığı ile tesis eder. Işık, oyunda bu anlamda bu mitolojik külliyatı hem meşrulaştıran hem de onun tarafından meşrulaştırılan aşkın şiddet mekanizması gibi hareket eder. Sahnedeki kaosu düzene sokarken toplumsal şiddeti rasyonel kılan sistemin bir temsili olarak çalışır. Birilerini görünür kılarken diğerlerini karanlığa gömer. Bazen de görünür kıldıkları üzerinde tahakküm kurar. Böylece sahnedeki anlatıyı şekillendirirken toplumsal düzeni sağlayan mekanizmayı somutlaştırır. Oyuncu ile ışık sahnenin unsurları olarak birbirlerine sıkı sıkıya bağlıdırlar. Oyuncunun sahne üzerinde görünür olması, oyunun geçici dünyasının sınırları içinde 1şı tarafından aydınlatılarak var edilmesi, kavramsal olarak insanın doğumu, ölümü ve yaşamdaki varoluşu ile de anlamlanır. Öte yandan, ışık aynı zamanda oyuncunun sahnedeki yaşamını sınırlandırır ve belirli koşullara bağlar. Rol kişilerinin/oyuncuların varlık alanları/oyun alanları onun tarafindan sınırlandırılıp tanımlanır ve böylelikle konumlarının farklılığı zorunlu hale gelir. Oyuncular sahnede serbestçe hareket edip birbirlerinin alanlarına giremezler çünkü ışık rol kişileri olarak hareket edebildikleri alanları sınırlandırır. İşte, onun bu somut yönelimi oyunun içinde onu aynı zamanda Zeus'un düzenini tesis eden bir mekanizmaya dönüştürür. Tıpkı Girard'ın üzerinde durduğu toplumun düzenini sağlama işlevini gören meşru şiddet olgusu gibi farklılık düzeninin sürdürülmesini sağlar.

En kapalı kültürlerde bile insanlar kendilerinin özgür ve evrensele açık olduklarına inanırlar; farklılaştırıcı karakterleri, en dar kültürel alanların bile, kendi içlerinden, tükenmezmiş gibi yaşanmasını sağlar, işte bu yanılsamayı tehlikeye atan her şey bizi ürkütür ve içimizdeki çok eskiden kalma klyımcı eğilimi uyandırır. Bu eğilim her zaman aynı yolu tutar, hep aynı basmakalıplarla vücut bulur, her zaman aynı tehdide karşılık verir. ${ }^{37}$

Rol kişilerinin ışık üzerlerine yandığında ona verdikleri cevaplar, yerine göre bu tehdit karşısındaki tavırlarını veya nihai durumlarını ifade eden birer anlam aracına dönüşür. Örneğin, 1şıkta susmak bazen korkuyu ifade ederken bazen bu düzene bir karşı gelişin işaretidir. Aynı zamanda oyun alanında tam ışık alan bölgeler olduğu gibi gölgede kalan bölgeler de vardır. Rol kişileri kimi zaman bir adımla bu gölgede kalan bölgelere girerler ve bu bölgede yine bazen susarak bazen de konuşarak anlam üretirler. Yarı 1şıkta/gölgede susmak veya konuşmak bazen kuşkuya, bazen meraka, bazen ise sorgulamaya ve isyana karşılık gelir.

Bir diğer düzlemde 1şık aynı zamanda Prometheus'un Zeus'tan çalıp insanlığa verdiği ateşi hatırlatır. Prometheus miti, ateşi çalarak insanlara veren titanın hikâyesini ve Zeus'un ona verdiği cezayı anlatır. Ateş, Zeus'un gücünü temsil eder ve Zeus bu gücü akıl ve bilgiden alır. Tekand'ın kurduğu hikâyede ateşin temsil ettiği bu güç insanlık tarafından Zeus'a geri teslim edilmiştir.

36 Girard, Şiddet ve Kutsal, 32.

37 Girard, Günah Keçisi, 36. 
İnsanlık kendi iradesiyle bu gücü kullanarak kendi özgürlügüünün sorumluluğunu almak yerine Zeus'un onlar için görünür kıldığı dünyayı onun gösterdiği şekilde kabul etmiş, böylece dünyanın sorumluluğunu almaktan kendini azat etmiştir. Bu durum sahneleme katmanında sahne üzerindeki kendi küçük oyun alanlarına sıkışmış oyuncuların durumu ile ifade edilir. Tekand, bu yorumu oyunun 4. epizotunda Prometheus’a söylettiği sözlerle de pekiştirir: “Insanlar ateşi Zeus'a geri teslim etti Io! [...] Şimdi o ateş onların üzerine yakıp kavuran bir ışık olarak geri yanslyor." 38 Işığın bu tanımı aynı zamanda modern Batı toplumunun "aydınlanma ve ilerleme" ütopyasıyla ve bu ütopyayı kuran araçlarla da hesaplaşmayı ima eder. Prometheus'un ağzından, insanlığa hediye edilen gerçeğin bilgisinin yine insanlığın elinde yıkım getirdiğini ifade eder Tekand oyunuyla. Prometheus 4. Epizotta, o insanlara ateşi verdikten sonra olup biten olaylarla ilgili şu sözleri söyler:

PROMETHEUS- Ben dünyaları aydınlanacak sandım. Onlarsa sadece yaktılar, yakıp yok ettiler emeksiz sahip oldukları ateşle. [...] Yürüyorlar ama hiçbir yere gitmiyorlar, koşuyorlar ama bir yere varmıyorlar. Yiyorlar, içiyorlar, bir türlü doymuyorlar. Yakıp kül ediyorlar her şeyi ama bir türlü ısınamıyorlar. Zeus'un oyuncakları gibi acz içinde çırpınıp duruyorlar. Ben akla, bilgiye sarılacaklar sandım onlara ateşi verirken, onlarsa sadece korktular, korkuya tutundular. Sahip olmaya, sonra da sahip olduklarını kaybetme korkusuna. Tıpkı Zeus gibi. ${ }^{39}$

Sahip olduklarını kaybetme korkusuna tutunan insanların durumu Koro'nun ışık altındaki hareketsiz durumuyla ifade edilir. Işık tarafından sınırları çizilmiş bu varlık alanında 1 şık altındaki yerine sahiplenmiş hareketsiz bir Koro ile başlar oyun. Ta yaratılış mitinden itibaren kurulmuş ve kabullenilmiş toplumsal düzeni ifade eder Koro'nun bu şekilde yerine mıhlanmış gibi kendisine verilmiş alanı koruyan tavrı. Işık ya da bu düzen tarafından izin verilen sınırların ve öğretilmiş/kabul edilmiş varoluş biçiminin ya da bilginin dışına çıkmak ölçüyü kaçırmak olacaktır. Bu düzene ve bilgiye dair herhangi bir sorgulama, iktidarın kendi varlığını üzerine inşa ettiği zeminin meşruluğunu da tartışmaya açacaktır. Bu durum var olan düzeni ve dengeyi sarsacağı için oyunda Koro, iktidarın bozulan düzeni ve dengeyi korumak için güç ve şiddet uygulamasından korku duyar. Dengenin, rahatın, konfor alanının bozulmasından duyulan korkudur bu. Diğer yanda konfor alanı, öncelikle bilinen ve görülebilenin içinde olmaktır, yani ışık tarafından aydınlatılan alanın içinde. Oysa ki, aslında görülebilen, görünüme sunulandan başka bir şey değildir. Bilgi kıyımcı iktidarın tekelinde olduğu için ışık da iktidardır, Zeus’tur ve ancak kendi belirlediği sınırlarda ve koşullarda var olma hakkını tanır. Işığın aydınlattığı alanın dışı yani iktidarın çizdiği sınırların dışı karanlık ve dolayısıyla bilinmez alandır. Sınırların dışına/ 1şığın aydınlattığı alanın dışına/ gölgenin veya karanlığın içine bakma ve hatta oraya adım atma düşüncesi korku yaratır. Konfor alanı aynı zamanda hareketsizlik tarafından ifade edilir, denge durumudur ve düzendir. Hareketsizlikte ve dengede bir şeylerin değişme ihtimali yoktur, kabullenme vardır ve bu da iktidarın işine gelir. Konfor da bir çeşit kabullenmedir.

38 Şahika Tekand, İo (İstanbul: Yayınlanmamış Oyun Metni, 2019), 56.

39 A.g.e., 55. 
Hatırlanmayan geçmişe giden yol karanlıktan geçer. Aydınlık var olanı görünür kılıyorsa, karanlıkta var olanlar sadece görünür değildir ama göze görünür olmamaları orada olmadıkları anlamına gelmez. Tıpkı bellek gibi... Dolayısıyla oyunda gölgeye girme, karanlığa girme, karanlığın içine bakma cesareti aynı zamanda hatırlama çabası, beynin karanlıklarında gizli olan bilgiyi tekrar aydınlatma cesaretidir. Koronun kuşkusu ve bildiklerini sorgulaması arttıkça, bu durum huzursuzluğa sebep olur ve onu hareketlendirir. Hareketlenen koronun bakış açısı genişler çünkü bedenin fiziksel olarak farklı yönlere yönelmeleri farklı perspektifler getirir. Işığın sınırlarının dışında başka varlık alanları olabileceğinin farkındalığg gelir.

\section{Günah Keçisinin Dönüşü}

Oyunda bir günah keçisi olarak Argos’tan sürülmüş İo'nun bu topraklara geri dönüşüyle onu günah keçisi olarak seçen mekanizmanın sorgulanması başlar. $\mathrm{O}$, kendisini bu kurbanlık sisteminden özgürleştirmek istemektedir. Böylece, İo'nun kendini savunması toplumun tarihsel bilincinin sarsılmasına neden olur. İo kendisi hakkında bilinenleri teker teker sorgular ve olayları bir de kendi bakış açısından anlatır. Böylelikle, halkın biat ettiği düzenin merkezindeki iktidarın, kendisini ve yaptığ 1 her şeyi meşrulaştıran bir yalan mekanizması üzerine kurulu olduğunu öne sürer; Zeus bu düzenin temsilcidir. İo bu mekanizmayı ifşa eder: "Zeus!!! Yıldırımlarına gerek yok, yalanların yetiyor gerçekleri yakmaya, yakıp küllerini havaya savurmaya! Olanı olmamış gibi, olmamışı da olmuş bilsin diye ölümlüler." ${ }^{40}$ Böylece mitolojide üstü örtülmüş olan şiddet açığa çıkar. Dışarıdan gelip Argos'un kapısına dayanan İo, anlattığı hikâyenin farklılığı ile Girard'ın deyimiyle "sistemin hakikatini, göreliliğini, kırılganlı̆̆ını, ölümlülüğünü açı̆ga çıkarır." "Sisteme son darbeyi de onu kurban olarak seçen ve ona suç yükleyen mekanizmanın adaletini sorgulayarak vurur; "Neden suçlu olan hep onun kurbanlart?"42 İo, y1llarca susmasının sebebinin kendini kurban gibi görmek olduğunu söyler. Kurban olmayı kabul ederek bu sistemin bir parçası olmuştur. Bunun yerine şiddetin açığa çıkmasını ister. Artık, her ne olursa olsun, her şeyi göze almak pahasına susmayacağını söyler. Başkalarının başına gelebileceklerin sorumluluğunu almak pahasına, gerçeği savunur. Girard'a göre günah keçileri kendilerini toplum için feda etmeyi seçerek kutsallaşırlar. İo, kutsallığından sıyrılıp dünyevi olmak ister. Öyle ki, oyunun üçüncü epizotunda, Hermes onu kendisiyle birlikte bütün halkı tehlikeye atmakla tehdit ettiğinde bunu zaten göze aldığını belirtir.

İo, böylece, Argos'a bir nevi kirlenmiş kurban kanı getirir. Eğer şehre alınırsa onun kirli kanının herkese bulaşma riski vardır ki nitekim oyunda böyle olur. İo'nun öfkesi ve isyanı toplumun kendi tarihini hatırlamasına sebep olur ve huzursuzluk insanlara bulaşmaya başlar. Bu bulaşıcılık oyunun hareket düzeninde de görülür. Hareketsiz ve duvar gibi duran Koro, oyun süresince yavaş yavaş hareketlenmeye başlar ve İo'nun huzursuz ve keskin hareket

40 A.g.e., 10.

41 Girard, Günah Keçisi, 35.

42 Tekand, İo, 12. 
niteliği herkese bulaşmaya başlar. Oyunun sorunda bütün Koro üyelerinin hareketlendiği görülür. Girard, bu kirlenmeyi ve bulaşıcılığı şöyle tarif eder; "Şiddet biçim degiştirerek nesneleri kaplayan bir tür sıvıya dönüşüyor ve bu sıvının yayımı, elektrik çarpmasına ya da Balzac'ın "manyetism”'ine benzer bir biçimde tümüyle fiziksel birtakım yasalara uyuyor gibi görünmeye başllyor." ${ }^{43} \mathrm{Bu}$ sözler, Koro üyelerine oyun süresince giderek artarak tesir eden rahatsız hareketliliği anlatır gibidir.

Ancak, İo ile Zeus'un temsilcileri arasındaki "stikomiti"44 diye adlandırılabilecek olan trajik diyaloğun simetrisi içinde gerçekleşen atışmalar çözümsüzdür. Bu noktada seyirciye çözümü son epizotta zincirleri çözülmüş olarak gelen Prometheus sunar. Prometheus'un oyuna girmesiyle yazar âdeta perspektif değiştirir. Prometheus, bütün bu mahkeme sürecine farklı bir perspektif getirerek Zeus'un mahkemesinin geçerliliğini sorgular. Ona göre, İo istediği kadar kendisini savunsun, Zeus'un mahkemesinde trajik çözümsüzlük durumunun içinden çıkılamayacaktır. Oyunun son epizotunda Prometheus bir anlamda oyunun üzerine kurulu olduğu mahkemenin kendisini yargılar. Trajik durumdaki ikiliği yaratan içinden çıkılmaz mekanizmanın kendisini sorgular. İo, günah keçisi olarak geri dönüp bu mekanizmayı sarsıp huzursuzluğu başlatmıştır. Prometheus ise bir üst bakış, âdeta yazarın ve yönetmenin bakışını temsil ederek bu mekanizmayı bütünüyle reddeder. İo ile Prometheus arasında geçen şu diyalog, İo'nun mücadelesine karşın Prometheus'un getirdiği perspektifi açık bir şekilde ortaya koyar:

IO-Yapayalnız tükettiğim şu sefil hayatta artık dayanamayacağımı zannettiğim çok zaman oldu Prometheus, öyle zamanlarda, bana söylediklerini tekrar tekrar içimden geçirirdim; sesinin yankısını kafamda duymaya, güç bulmaya çalışırdım.

PROMETHEUS- Gücü ister Zeus 'ta ister bende ister başka bir ölümsüzde arasın ölümlüler; bu yanlış Io!

$[\ldots]$

PROMETHEUS- Sen Zeus'un insanlara neler yaptığı̆n değil insanların kendilerinin neler yaptı̆̆ını izledin Io. İnsanların neler yapmayı seçtiklerini gördün. İnsanlar uzun zamandır ya her şeyi bırakıyor Olympos'a tembelce ya da bir şey yapmak yerine acılara katlanıyorlar. Iradelerini unutup buna da huzur diyorlar. ${ }^{45}$

Prometheus, İo'nun adalet arayışını dayandırdığı güç mücadelesinin her durumda aynı sistemi meşrulaştıracağını öne sürer. Onun önerisi, bir kez daha dünyayı insanlığa ve insanlığın iradesine teslim etmektir; açığa çıkmış şiddetin üstünü tekrar örtmek yerine onunla yüzleşmektir: "PROMETHEUS- Ey Dünya! İstemesen de bir gün Olympos’u taklit etmekten vaz geçeceksin!”46

43 Girard, Şiddet ve Kutsal, 39.

44 Trajik diyaloğun kusursuz simetrisi biçim açısından iki kahramanın birer dizeyle atıştığı stikomiti' de somutlaşır: "Trajik diyalog düellodaki demirin yerini sözlerin almasıdır. Şiddet ister fiziksel ister sözsel olsun trajik gerilim değişmez.” A.g.e., 61.

45 Tekand, İo, 53.

46 A.g.e., 57. 
$\mathrm{Bu}$ noktada oyunun birinci epizotunda koronun kendisini tanımlama biçimine kısaca değinmek yerinde olacaktır: "Biz insanız, felaketine acırız ama lanetlerden korkarız." ${ }^{47}$ Halbuki, oyun boyunca acıdan ve korkudan arınma gerçekleşir. Oyunun sonunda insanlık sahnede yalnız kalmıştır. Zincir kopmuştur. Boşluğun ve karanlığın içinde kendi yolunu bulmak üzere onu sisteme bağlayan zincirlerinden kopmuş halde meşale Prometheus tarafindan insanlığa tekrar devredilmiştir. İnsanlık ve ışık baş başa kalır; yeniden başlamak üzere...

\section{Sonuç}

İo'nun, mitleri, kahramanları, anti kahramanları, aslında insanlığın içinde yaşadığımız çağdaş dünya düzeninin işleyişini mümkün kılmak için yarattığı her şeyi eleştiren ve üstü örtülü şiddeti açığa çıkaran metni ve sahnelemesi, asıl değişimin radikal bir yüzleşme ve sistemin döngüsünden çıkışla gerçekleşebileceğini söyler.

Burada sözü edilen sistemin -insanın dünyadaki var oluş koşulunu belirleyen her şeyintrajik döngüsünü, günah keçisi ve kurban olgularıyla ilişkilendirerek, şiddetin toplumların var oluşlarının temelinde nasıl bir tarihsel mekanizmayla ortaya çıktığını ve işlediğini analiz eden Girard'ın sunduğu bakış açısı İo'nun yapıbozumuna uğratmayı amaçladığı meseleyi aydınlatır. Girard, tarihi yazanların kıyımcı bakış açısının açığa çıktığı anlatılar aracılığıyla gerçekleşen kıyıma işaret eder. Í , bakışımızı bu kıyıma yöneltirken şiddetin sadece gerçekleşmiş kıyımın kendisinde değil, onun çarpıtılmasında, aynı zamanda unutulmasında, hatırlandı̆̆ında susulmasında ve eylemsizlikte de var olduğunu ifade eder. Prometheus'un son epizotta, insanlığı, gücü ve sorumluluğu kendisinden daha yüksek mertebede varlıklara/kişilere/sistemlere teslim etmekten ve kendini dünyanın sorumluluğunu almaktan muaf tutmak için bu varlıkları/kişileri/ sistemleri yaratmak yerine, kendi gücünü ve iradesini sahiplenmeye davet ettiği açıktır.

Peer-review: Externally peer-reviewed.

Conflict of Interest: The author has no conflict of interest to declare.

Grant Support: The author declared that this study has received no financial support.

Hakem Değerlendirmesi: Dış bağımsız.

Çıkar Çatışması: Yazar çıkar çatışması bildirmemiştir.

Finansal Destek: Yazar bu çalışma için finansal destek almadığını beyan etmiştir.

\section{KAYNAKÇA/ BIBLIOGRAPHY}

Aiskhülos. Oresteia: Agamemnon, Adak Sunucular, Eumenidler, çev. Y1lmaz Onay. İstanbul: Mitos Boyut Yayınları, 2016.

47 A.g.e., 8 . 
Aiskhylos. Zincire Vurulmuş Prometheus, çev. Azra Erhat, Sabahattin Eyüboğlu.

İstanbul: İş Bankası Yayınları, 2000.

Anhalt, Emily K. "The Tragic Io: Defining Identity in a Democratic Age.” New England

Classical Journal 42,/4 (2015), 246-260.

Arıcı, Oğuz. "Muğlâklık ve Tragedya.” Doktora tezi, İstanbul Üniversitesi, 2009.

Erhat, Azra. Mitoloji Sözlüğ̈̈. İstanbul: Remzi Kitabevi, 2011.

Girard, René. Günah Keçisi, çev. Işık Ergüden. İstanbul: Alfa Yayınları, 2018.

Girard, René. Şiddet ve Kutsal, çev. Necmiye Alpay. İstanbul: Kanat Yayınları, 2003.

Herodotos. Herodot Tarihi, çev. Müntekim Ökmen. İstanbul: Türkiye İş Bankası Kültür Yayınları, 2002.

Konstantinou, Ariadne. "Reconsidering the Metamorphosis of Io: on Texts, Images and Dates", Symbolae Osloenses 89/1 (2015), 35-53.

Lévi-Strauss Claude. Mit ve Anlam, çev. Gökhan Yavuz Demir. İstanbul: İthaki, 2013.

Smith, William. Dictionary of Greek and Roman Biography and Mythology. vol 2. Boston: Little, Brown and Co., 1870 .

Tekand, Şahika. İo. İstanbul: Yayınlanmamış Oyun Metni, 2019.

Tekand, Şahika. "İo Reji Notları”, İstanbul: 2019.

Uğurlu, Ahmet. “Claude Lévi-Strauss’ta Mitos”, Insan \& Toplum Dergisi 4/7 (2014), 113-133. 